\title{
REALITAS PEMBELAJARAN KONTEN KEISLAMAN DAN KEINDONESIAAN DI PONDOK PESANTREN HIDAYATULLAH BALIKPAPAN
}

\section{THE REALITIES OF LEARNING WITH ISLAMIC AND INDONESIAN ERUDITIVE CONTENT AT ISLAMIC BOARDING SCHOOL OF HIDAYATULLAH BALIKPAPAN}

\author{
Firman \\ Dirasat Islamiah Pascasarjana UIN Alauddin Makassar \\ Email: firman@uniba-bpn.ac.id
}

Bahaking Rama

Fakultas Tarbiyah dan Keguruan Universitas Islam Negeri Alauddin Makassar

Email: bahaking.rama@yahoo.co.id

Muljono Damopolii

Fakultas Tarbiyah dan Keguruan Universitas Islam Negeri Alauddin Makassar

Email: muldafat@yahoo.com

\section{Shabir $U$.}

Fakultas Tarbiyah dan Keguruan Universitas Islam Negeri Alauddin Makassar Email: shabiru@uin-alauddin.ac.id

Naskah diterima tanggal 19 Maret 2020, Naskah direvisi tanggal 9 April 2020, Naskah disetujui tanggal 9 Juni 2020

\begin{abstract}
Abstrak
Penelitian ini bertujuan mengkaji bagaimana realitas pembelajaran konten keislaman dan konten keindonesiaan di Pondok Pesantren Hidayatullah Balikpapan. Jenis penelitian ini adalah deskriptif kualitatif sehingga peneliti mencari makna, pemahaman, fenomena, kejadian, maupun keadaan yang berkaitan dengan pembelajaran konten keislaman dan keindonesiaan di Pondok Pesantren Hidayatullah Balikpapan. Sumber data yaitu data primer melalui wawancara dan data sekunder melalui dokumen. Adapun instrumen penelitian adalah peneliti sendiri sebagai instrumen kunci dan pedoman wawancara. Sedangkan teknik analisis data dengan menggunakan reduksi data, displai data, kemudian dilakukan verifikasi. Hasil penelitian menunjukkan bahwa Pertama, Pembelajaran keislaman di Pondok Pesantren Hidayatullah Balikpapan secara garis besar terdiri atas tauhid, ibadah, dan akhlak. (1) Pembelajaran tauhid yaitu pembelajaran untuk mentauhidkan Allah dengan cara semua materi pelajaran dilandasi dengan nilai-nilai tauhid. (2) Ibadah, yaitu pembelajaran diniyah, Baca al-Qur'an, Tahfiz, Tahsin, Salat lail, Ta'lim, Halaqah al-Qur'an. (3) Akhlak, yaitu melatih kemandirian, hidup sederhana, memiliki kepribadian akhlak al-karimah, sikap menghormati, menjaga hubungan baik dengan teman sesama santri, menghormati warga pondok. Kedua, Pembelajaran Keindonesiaan, yaitu PKn, Bahasa Indonesia, Matematika, IPS dan adanya Sosialisasi Empat Pilar yaitu Pancasila, UUD 1945, NKRI, Bineka Tunggal Ika. Pembentukan Satuan Komunitas (SAKO) Pramuka Hidayatullah, dan bela diri.
\end{abstract}

Kata Kunci: pembelajaran, keislaman, dan keindonesiaan

\section{Abstract}

This study aims to examine the realities of learning with Islamic and Indonesian eruditive content at Islamic Boarding School of Hidayatullah Balikpapan. This research employs descriptive qualitative methodology. Therefore, the researcher attempted to seek for understanding, phenomena, events, and circumstances related to the learning of Islamic and Indonesian content at the school. The data sources were gained through the primary data of interviews and the secondary data of 
documentation. The research instruments used were the researcher himself and interview guides. The data analysis techniques used were data reduction, data display, and data verification. The results of the research showed that firstly, Islamic materials received at the school were consisted of monotheism, worship, and morals. Secondly, Indonesian Eruditive Learning was consisted of civics education, Indonesian language, Social science and four pillars socialization of Pancasila, the 1945 Constitution, NKRI, and Bhineka Tunggal Ika.

Keywords: learning, islamic, indonesian eruditive content

\section{PENDAHULUAN}

$\mathrm{F}$ enomena yang terjadi akhir-akhir ini dalam dunia pendidikan sedang dilanda isu intoleran, anti Pancasila dan anti kebinekaan yang menyeret para siswa di sekolah untuk terlibat dalam kelompok tersebut dengan alasan penegakan syariat Islam, keadilan, dan pemerintahan. Pertanyaannya apa yang terjadi dalam dunia pendidikan kita? apakah guru mengajarkan nilai-nilai seperti itu, apakah jiwa kebangsaan sudah tidak tertanam lagi di kalangan pelajar? Inilah pertanyaan masyarakat yang muncul di tengah bangsa multikultur terhadap persoalan pendidikan dan kebangsaan. Kejadian tersebut juga ikut membawa nama pondok pesantren yang selama ini dikenal sebagai gudangnya ilmu agama.

Untuk diketahui bahwa lembaga pendidikan Islam yang pertama di Indonesia adalah pondok pesantren. Pondok pesantren merupakan lembaga pendidikan asli Indonesia yang sampai saat ini masih menjadi tujuan bagi peserta didik Indonesia untuk memperdalam pengetahuan ilmu keagamaan yang berkembang berdasarkan ciri dan tipologi masing-masing. Lembaga kepesantrenan menjadi warisan kekayaan bangsa yang patut untuk dijaga dan dilestarikan karena pesantren menjadi pilar penting dalam kehidupan bangsa Indonesia. Pondok pesantren telah melahirkan banyak tokoh nasional yang telah berkontribusi dalam memperjuangkan dan membangun bangsa Indonesia.

Keberadaan pondok pesantren menjadi penting untuk mengurai persoalan yang terjadi di masyarakat termasuk lahirnya paham-paham yang mengarah pada perpecahan bangsa seperti intoleran, menolak ideologi bangsa, menganggap paham mereka yang benar dan berbagai fenomena yang terjadi dalam masyarakat dengan mengatasnamakan Islam. Inilah menjadi tantangan para lembaga pendidikan Islam termasuk pondok pesantren dan guru agama. Realitas ini menggugah para guru Pendidikan Agama Islam di sekolah bahwa ada bahaya yang mengintai para siswa mereka dan apabila gerakan ini dibiarkan bukan hanya mengancam siswa melainkan akan menjadi masalah besar dalam kehidupan beragama dan berbangsa.

Mencermati fenomena tersebut, maka penting untuk dilakukan pembelajaran di pondok pesantren dengan pendalaman tauhid, ibadah, dan akhlak. Selain pembinaan keagamaan, pembinaan dan pemahaman nilainilai kebangsaan atau keindonesiaan menjadi kebutuhan para santri untuk mencintai tanah airnya agar tercipta hubbul wathan selanjutnya menjadi bangsa yang Baldatun Toyyibatun $W a$ rabbun Ghafur. Nilai-nilai Pancasila, NKRI, Konstitusi, maupun kebinekaan menjadi konsumsi penting bagi santri jangan sampai haus jiwa nasionalismenya akhirnya masuk paham yang merusak bukan hanya jiwa kebangsaan tetapi pemahaman agama yang salah. Oleh karena itu, dalam penelitian ini, peneliti mengkaji realitas pembelajaran keislaman dan keindonesiaan di Pondok Pesantren Hidayatullah Balikpapan.

Bila melihat perjalanan Pondok Pesantren Hidayatullah Balikpapan merupakan pesantren yang berbeda dengan konsep pesantren pada umumnya tidak hanya fokus bidang pendidikan melainkan gerakan dakwah dan sosial. Selain itu, merangkum berbagai golongan termasuk pemerintah menjadi mitra dalam usaha pengembangan gerakan pondok. Konsep ini sejalan dengan gagasan yang dikemukakan oleh Munawir Sjadzali bahwa Pancasila sebagai Ideologi negara yang secara substantif adalah nilainilai Islam (Toharudin, 2018). 
Menurut Muhammad Tang S. (Tang S, 2017) sebagaimana mengutip pendapat K.H. Abdullah Said bahwa sumber utama kemerosotan umat Islam adalah tidak berjalannya pendidikan keimanan secara benar sehingga syahadat yang semestinya menghantarkan umat pada kecintaan pada ilmu dan jihad menjadi tergerus sedemikian rupa. Gerakan Pondok Pesantren Hidayat ullah sebagai lembaga pendidikan sebagai pusat pembinaan mental spiritual maupun akhlak sehingga pendidikan diarahkan untuk pembinaan moral santri. Oleh karena itu, hanya santri yang memiliki akhlak dan ibadah yang baik bisa menjadi pendidik, melaksanakan dakwah dan gerakan sosial.

Berdasarkan latar belakang tersebut, maka dapat dijabarkan dalam bentuk rumusan masalah yaitu bagaimana pembelajaran konten keislaman dan keindonesiaan di Pondok Pesantren Hidayatullah Balikpapan? tujuan penelitian ini adalah untuk mengkaji pembelajaran konten keislaman dan keindonesiaan pada Pondok Pesantren Hidayatullah Balikpapan. Sedangkan manfaat penelitian menjadi bahan renungan bagi pondok pesantren untuk menerapkan sistem pembelajaran keislaman dan keindonesiaan sebagaimana yang dilaksanakan di Pondok Pesantren Hidayatullah Balikpapan untuk memperkuat nilai-nilai Islam berupa tauhid, ibadah, dan akhlak kemudian nilai keindonesiaan untuk menghindari terjadinya sikap intoleran, anti Pancasila, dan anti keragaman serta polarisasi pendidikan.

\section{TINJAUAN PUSTAKA}

Oemar Hamalik menjelaskan bahwa pembelajaran adalah suatu kombinasi yang tersusun meliputi unsur-unsur manusiawi, material, fasilitas, perlengkapan, dan prosedur yang saling mempengaruhi mencapai tujuan pembelajaran. Manusia terlibat dalam sistem pengajaran terdiri dari siswa, guru, dan tenaga lainya misalnya tenaga laboratorium, material meliputi buku-buku, papan tulis, spidol, kapur, fotografi, slide dan film, audio dan video tape. Fasilitas dan perlengkapan terdiri at as ruangan kelas, perlengkapan audio visual juga komputer. Prosedur, meliputi jadwal dan metode penyampaian informasi, praktik belajar, ujian dan sebagainya (Oemar Hamalik, 2013). Oleh karena itu, pembelajaran merupakan proses transfer pengetahuan dengan menggunakan beberapa unsur termasuk materi dan fasilitas, alat, dan sesuai dengan prosedur sehingga mampu mencapai tujuan pembelajaran.

Dalam penelitian Toharuddin yang mengelaborasi pemikiran Munawir Sjadzali, bahwa Islam menurut Munawir Sjadzali adalah sebuah sistem yang menurut penganutnya untuk aktif mewujudkan dalam kehidupan umat Islam didunia nyata artinya nilai-nilai Islam diamalkan dalam kehidupan termasuk dalam bernegara. Kemudian untuk membangun peradaban Indonesia yaitu dengan mereaktualisasikan nilai keislaman dan keindonesiaan. Pancasila sebagai ideologi bangsa Indonesia secara substantif adalah nilai-nilai Islam. Artinya bahwa dalam Pancasila sebagai dasar negara memiliki nilainilai Islam sehingga tidak perlu untuk dipertentangkan apalagi mengganti ideologi. (Toharudin, 2018)

Mencermati pandangan tersebut, maka Pancasila sebagai ideologi negara sudah final. Oleh karena itu, tidak ada lagi pertentangan antara Pancasila sebagai dasar negara dan Islam. Konsep keislaman dikaitkan dengan konsep keindonesiaan dalam realitas menunjukkan bahwa memiliki hubungan erat. Hal ini dapat dilihat bahwa konsep tauhid dalam Islam juga dalam kehidupan berbangsa dengan ideologi Pancasila terdapat sila pertama yaitu Ketuhanan Yang Maha Esa. Demikian juga dalam konstitusi negara Republik Indonesia disebutkan bahwa Indonesia berdasarkan Ketuhanan Yang Maha Esa.

\section{METODE PENELITIAN}

Jenis penelitian ini adalah deskriptif kualitatif, sehingga peneliti mencari informasi tentang makna, pemahaman, fenomena, kejadian, maupun keadaan yang berkaitan dengan pembelajaran konten keislaman dan keindonesiaan di Pondok Pesantren Hidayatullah Balikpapan. Lokasi penelitian yaitu di Pondok Pesantren Hidayatullah Balikpapan Kelurahan Teritip Balikpapan Timur Kota Balikpapan. Sumber data yaitu data primer melalui wawancara dan data sekunder melalui dokumen. Adapun instrumen penelitian adalah keterlibatan peneliti sebagai instrumen kunci dalam 
penelitian ini dan pedoman wawancara. Sedangkan teknik analiasis data dengan menggunakan reduksi data, displai data, kemudian melakukan verivikasi. Jadi penelitian ini mendeskripsikan keadaan yang sebenarnya tentang realitas pembelajaran yang terjadi di Pondok Pesantren Hidayatullah Balikpapan yaitu bagaimana pembelajaran keislaman dan keindonesiaan terhadap santri.

\section{PEMBAHASAN}

\section{Pembelajaran Konten Keislaman}

Makna Pembelajaran konten keislaman adalah pembelajaran yang di dalamnya menyangkut nilai-nilai Islam. Konsep pembelajarannya di kelas dan di luar kelas berbeda, pada umumnya di kelas menggunakan masing-masing metode berdasarkan kompetensi dasar yang diajarkan oleh guru. Sedangkan pembelajaran diluar kelas pembelajaran tidak terikat secara formal dengan mengangkat isu-isu Islam. Di Pondok Pesantren Hidayatullah Balikpapan pembelajaran keislaman secara garis besar terdiri atas tiga tema yaitu Tauhid, Ibadah, dan Akhlak.

Menurut Muhammad Tang tujuan pendidikan Pondok Pesantren Hidayatullah Balikpapan selaras dengan misi penciptaan manusia yaitu menjadi abid dan khalifah Allah. Oleh karena itu, sebagai hamba Allah maka manusia harus memiliki karakter tiga hal yaitu; pertama, memiliki sikap mental spritual yang kokoh (aspek ruhiyah); kedua, menguasai ilmu pengetauan dan wawasan yang luas (aspek aqliyah); ketiga, mempunyai keahlian dan keterampilan (aspek jismiyah). Lembaga pendidikan pondok pesantren Hidayatullah Balikpapan bertujuan melahirkan generasi memiliki kepribadian yang cerdas, beriman dan bertakwa kepada Allah swt. serta berakhlak mulia. Untuk mencapai tujuan tersebut maka meletakkan dan menjadikan al-Qur'an sebagai paradigma dalam berbagai aspek kehidupan (Tang S, 2017).

Lebih lanjut (Tang S, 2017) mengatakan bahwa dengan berpijak pada alQur'an dan hadis akan melahirkan generasi muslim yang cerdas, kreatif, mandiri, dan bermanfaat bagi lingkungan masyarakat. kondisi tersebut ditunjukkan dengan empat karakter yakni berkepribadian Islam, menguasai tsaqafah Islam, menguasai ilmu kehidupan dan memiliki keahlian yang memadai. Itulah yang menjadi tujuan pendidikan pondok Pesantren Hidayatullah Balikpapan, sehingga tercapai visi menjadi lembaga yang unggul, amanah, dan terampil.

Dengan berpijak pada al-Qur'an, maka al-Qur'an menjadi paradigma dalam kehidupan sehari-hari, sehingga segala aktivitas diwarnai dengan nilai-nilai alQur'an. Konsep paradigma al-Qur'an menjadi konsep pendidikan di Pondok Pesantren Hidayatullah Balikpapan dengan konsep sistematika wayhu. Sistematika wahyu akan diuraikan dalam pembelajaran konten keislaman yaitu Tauhid, Ibadah, dan Akhlak.

\section{Tauhid}

Sesuai asas kurikulum Pondok Pesantren Hidayatullah Balikpapan yaitu tauhidullah, maka setiap pembelajaran adalah melekatkan nilai-nilai tauhid pada materi yang diajarkan kepada santri. Proses peningkatan mening nilai ketauhidan pada maka setiap santri mempunyai kewajiban mengaktualisasikan dalam keseharian baik dalam proses belajar di kelas maupun di asrama, di masjid, dan lingkungan masyarakat.

Menurut Abdul Gofar Hadi Ketua LPPH Balikpapan salah satu momen terpenting dalam menanamkan nilai tauhid kepada santri di luar kelas yaitu pada saat Ta'lim yang dilaksanakan ba'da Magrib dari senior, tamu, teman dari daerah memberikan pengalaman di tempat di mana ditugaskan untuk melaksanakan pendidikan dan dakwah dengan tanpa keluarga, teman, dan bekal untuk melaksanakn tugas mulia. Berbagai kendala yang mereka hadapi, tetapi dengan keteguhan iman mereka mampu bertahan untuk melaksanakan tugas contoh di tempat yang minoritas muslim seperti di Papua

Untuk meningkatkan ketauhidan maka praktik ketauhidan yang diterapkan dalam kehidupan kehidupan sehari-hari sebagai berikut: 
1. Baca al-Qur'an yaitu dengan mentadabburi salah satu rukun iman (iman kepada kitab)

2. Memperkuat keyakinan kepada kemahakuasaan Allah dengan melaksanakan salat malam.

3. Meyakini kemaha pemurahan Allah melalui puasa senin kamis.

4. Memperkuat keyakinan kepada tentang kasih sayang Allah melalui salat berjamaah di masjid.

5. Menghindari segala bentuk yang mengarah kepada kemusyrikan.

Dengan praktik tersebut membentuk santri menjadi santri yang beriman dan bertakwa. Santri yang beriman dan bertakwa memposisikan dirinya sebagai hamba Allah sehingga terbentuk ciri dalam kehidupannya. Hal ini sejalan yang telah sebutkan Ahmad Tafsir(Tafsir, 2013) yang menyebutkan bahwa ciri orang yang beriman adalah:

1. Mempercayai dan mengamalkan ajaran Tuhan dalam bidang ritual;

2. Berbudi pekerti luhur;

3. Berpengetahuan dan berketerampilan;

4. Sehat jasmani dan rohani;

5. Berkepribadian yang mantap;

6. Mandiri;

7. Memiliki rasa tanggung jawab kemasyarakatan dan kebangsaan.

Secara umum pembelajaran keislaman berasaskan konsep sistematika wahyu, dengan berlandaskan sistematika turunya al-Qur'an yang dimulai ayat pertama turun. Dari ayat tersebut Allah memperkenalkan dirinya melalui wahyu yang pertama turun yaitu AlAlaq/96: 1-5. Setelah surat Al-Alaq kemudian surat Al-Qalam, Al-Muzammil, Al-Mudatsir, dan Al-Fatihah. Dalam praktiknya konsep sistematika wahyu tidak diterapkan secara umum melainkan berdasarkan jenjang pendidikan santri misalnya surat Al-Alaq cukup diterapkan di tingkat MTs, sedangkan pembahasan lebih mendalan ke surah berikutnya pendidikan lebih tinggi atau orang dewasa.

Sebagai contoh QS Al-Alaq ayat 1-5, konsep tauhid menurut Abdullah Said (Manshur Salbu, 2012: 269) bahwa Allah swt. menurunkan ayat pertama memiliki makna yang sangat luar biasa bila dikaitkan dengan ketauhidan. Lebih lanjut Abdullah Said, mengatakan bahwa ada beberapa contoh bentuk keluarbiasaan ayat pertama ini turun yaitu pengakuan Abu Bakar Ash Siddiq tanpa mempertibangkan kemudian ikut melebur dalam perjuangan Islam. Contoh lain setelah ayat al-Qur' an turun perubahan secara drastis masyarakat Quraisy.

Secara kontekstual ayat tersebut menjawab permasalahan yang terjadi masyarakat bangsa Arab yang dikenal jaman jahiliyah. Berbagai kejahatan, perbuatan tercela, kemusyrikan, serta tidak ada lagi penghormatan pada nilai-nilai kemanusiaan, khususnya kaum perempuan. Para elit bangsa Arab berselingkuh dengan kejahatan seperti minum arak, berjudi, berzina, mengundi nasib dan bahkan tidak lagi mengenal Tuhannya, sehingga menciptakan Tuhan sendiri. Dengan kehadiran al-Qur'an mampu merubah peradaban secara revolusioner khususnya dari aspek tauhid.

Menurut Syamsul Rizal Palu penerapan konsep sistematika wahyu menjadi model pendidikan di pesantren Hidayatullah. Tetapi dalam penerapannya tidak semua jenjang pendidikan karena daya tangkap terhadap konsep ini tidak mampu bagi santri RA MI dan untuk MTs hanya penerapannya pada surat Al-Alaq. Jadi tidak semua konsep sistematika wahyu diterapkan kepada santri. Konsep ini dianggap mampu menjawab problematika umat Islam terutama nilai-nilai dasar tauhid, sebagai pondasi dalam berislam.

\section{Ibadah}

Arah pendidikan yang akan dicapai santri dalam pondok pesantren adalah merubah nilai atau tatanan dalam kehidupan. Karena itu peran kiai menjadi penyaring yang merasuk ke dalam lingkungan santri untuk mewariskan apa yang dianggap bermanfaat dan membuang apa yang bisa merusak santri. Dengan konsep ini maka pesantren memiliki peran penting dalam mengontrol perkembangan budaya. Oleh karena itu, peran kiai maupun guru di pondok mempunyai peran dalam membentuk karakter dan pribadipribadi muslim yang mantap ibadahnya.

Terkait dengan arah dan cita-cita Pondok Pesantren Hidayatullah Balikpapan dalam implementasi cita-cita Islam yaitu 
dengan membekali santri ilmu agama dan ilmu pengetahuan umum. Pengetahuan agama mendidik untuk menguasai ilmu agama dan hukum-hukum agama dan pembentukan akhlak mulia. Oleh karena itu, seoarang santri sebelum terjun ke masyarakat, maka terlebih dahulu mengontrol diri apakah perilaku sudah sesuai dengan kaidah agama, seperti kejujuran, kesopanan, akhlak, serta ibadahnya. Sedangkan pengetahuan umum menjadi bekal para santri untuk membekali diri keterampilan baik berupa keahlian maupun kemampuan bersosialisasi di masyarakat.

Sehubungan dengan hal tersebut, maka Pondok Pesantren Hidayatullah Balikpapan berupaya membentuk menjadi santri shaleh, cerdas, dan berakhlak mulia. Untuk mencapai tujuan tersebut langkahlangkah yang lakukan Pondok Pesantren Hidayatullah Balikpapan sebagai berikut: 1)

Pembelajaran diniyah; 2) Baca alQur'an; 3) Tahfiz (target harus hafal 3 juz khusus siswa MTs); 4) Tahsin; 5) Salat lail 6) Ta'lim; 7) Baca surat Al-Kahfi setiap malam jumat; 8) Halaqah al-Qur'an; dan 9) Ceramah umum.

Menurut Abdullah Said makna QS AlQalam/68:17. menggambarkam bahwa orang tidak ber-Qur'an sebagai manusia yang dilanda kegilaan. Gila karena tidak menjadikan al-Qur'an sebagai paradigma dalam kehidupan, sehingga salah dalam memandang kehidupan, menghabiskan waktu maupun kesempatan pada hal-hal yang tidak penting. Dengan demikian banyak orang menghabiskan waktu hanya untuk kepentingan duniawi bekerja non-stop dan meninggalkan kehidupan akhirat. Itulah salah bentuk kegilaan cara pandang dalam hidup yang salah (Salbu, 2012)). Oleh karena itu, alQur'an harus menjadi pedoman dalam menata hidup baik dalam pendidikan, ekonomi, politik, budaya, hukum, dan sebagainya. Dengan menjalankan ibadah dengan benar dan menjadikan al-Qur'an sebagai paradigma dalam hidup, maka akan menjadi santri yang cerdas, shaleh, dan berakhlak. Dengan begitu terbentuk insan kamil sesuai dengan tujuan Islam.

Keterkaitan dengan ibadah Sudarsono dalam penelitiannya menyebutkan bahwa dalam dinamika hidup manusia di muka bumi seharusnya semua didasarkan pada prinsipprinsip ubudiyah, baik dalam bidang politik, ekonomi, sosial, budaya kemasyarakatan dan sebagainya. Konsep ini diadopsi dari alQur'an pada QS Al-Dzariyat: 56 bahwa sesungguhnya jin dan manusia diciptakan untuk mengabdi kepada Allah, sehingga segala aktivitas hidup manusia dilandasi dengan nilai ibadah.(Hadits, 2018)

\section{Akhlak}

Pembinaan akhlak pada santri Pondok Pesantren Hidayatullah Balikpapan juga menjadi perhatian serius. Pembinaan ini mempunyai alasan rasional yaitu pembentukan generasi Qur'ani. Generasi Qur'ani adalah generasi yang menanamkan nilai-nilai al-Qur'an dalam dirinya dengan mengaktualisasikan dalam kehidupan di antaranya memiliki karakter akhlak mulia. Bagaimana membentuk generasi Qur'ani yaitu mengakrabkan santri dengan al-Qur'an, menghafal, mengetahui maknanya, dan mengamalkan dalam kehidupan.

Untuk membentuk karakter akhlak, maka santri dalam kehidupan di asrama maupun di sekolah mematuhi aturan yang berlaku dan ketika melanggar at uran diberikan sanksi. Pemberlakuan aturan sebagai upaya pembentukan akhlak mulia terhadap santri. Selama peneliti melakukan observasi menemukan bahwa santri wajib memakai baju warna putih sehingga tidak ada kesan perbedaan yang nampak di kalangan santri. Demikian halnya ketika bertemu dengan orang yang lebih dewasa mereka hormat dan memberi salam. Budaya berpakaian tampak menjadi tradisi di lingkungan pondok maupun masyarakat di sekitar pondok yaitu warna cara pakaian dengan berwarna putih.

Upaya ini dilakukan untuk membentuk pribadi santri sesuai dengan tujuan pondok maupun visi madrasah yaitu pembentukan akhlak mulia. Hal ini dimaksudkan agar santri terbiasa dengan praktik dalam kehidupan sehari seperti: 1) Melatih kemandirian; 2) Hidup sederhana; 3) Memiliki kepribadian akhlak al-karimah; 4) Sikap menghormati; 5) Menjaga hubungan baik dengan teman sesama santri; 6) 
Menghormati warga pondok; 7) Hidup berinteraksi dengan masyarakat di sekitar lingkungan pondok.

Persoalan akhlak menjadi perhatian masyarakat termasuk lembaga pendidikan,khususnya lembaga pendidikan Islam. Oleh karena itu, materi tentang akhlak harus memiliki materi yang banyak ditambah dengan muatan materi agama yang lain. Pembinaan terhadap budi pekerti menjadi perhatian pemerintah sehingga pendidikan agama di lembaga pendidikan umum menjadikan agama sebagai salah satu penentu kenaikan kelas. Akhlak yang dimaksud adalah akhlak islami yaitu akhlak berdasarkan alQur'an dan hadis.(wahidin, unang; Ahmad, 2018)

\section{Pembelajaran Konten Keindonesiaan}

Di tengah maraknya tudingan miring pada lembaga pendidikan tentang gerakan radikal, maka pendidikan dipesantren tidak cukup hanya pengetahuan agama seperti pembacaan kitab, tauhid, akhlak, ibadah, bahasa arab, dan sejarah Islam serta ilmu agama lainnya melainkan penting pengajaran kehidupan berbangsa dan bernegara dengan menguatkan pembelajaran konten keindonesiaan.

Pembelajaran konten keindonesiaan, seperti dalam kurikulum yang diterapkan di Pondok Pesantren Hidayatullah yaitu mata pelajaran Bahasa Indonesia, PKn, IPA, IPS, Matematika, Olah Raga dan Seni Budaya. Selain pembelajaran yang dilaksanakan di kelas para santri juga disuguhkan beberapa kegiatan untuk menanamkan nilai-nilai keindonesiaan pada setiap santri seperti adanya sosialisasi empat pilar yaitu Pancasila, UUD 1945, NKRI, Bhineka Tunggal Ika.

Sosialisasi empat pilar dalam kehidupan berbangsa dan bernegara sesuatu yang harus dipahami oleh setiap warga negara termasuk para peserta didik sebagai calon pemimpin masa depan, serta seluruh masyarakat dan menjadi panduan dalam kehidupan dalam interaksi sosial kemasyarakatan, dan termasuk berbagai dimensi kehidupan. Dengan begitu, selain aturan dalam pesantren menjadi pedoman dalam penyelenggaraan pendidikan, maka empat pilar juga menjadi panduan dalam proses pelaksanaan pendidikan di pesantren.
Menurut Abdul Ghofar Hadi ketua Lembaga Pendidikan Pengkaderan Hidayatullah (LPPH) Balikpapan) Sosialisasi empat pilar dilaksanakan secara berkala dengan mendatangkan anggota MPR RI di antara anggota MPR yang pernah hadir adalah ketau MPR Zulkifli Hasan dan perwakilan dari Kalimantan Timur K.H. Aus Hidayat. Sudah menjadi kewajiban para anggota MPR RI melakukan sosialisasi maka kesempatan ini dimanfaatkan oleh pengurus Yayasan Pondok Pesantren Hidayatullah Balikpapan. Hasil dari sosialisasi ini ketika dilakukan tes perwakilan santri pada umumnya mereka paham tentang dasar-dasar Pancasila, UUD 1945, NKRI, dan Bhineka Tunggal Ika.

Kemudian Mursyid (kepala sekolah MTs. Raadhiyatan Mardhiyyah Putra Pondok Pesantren Hidayatullah Balikpapan) menambahkan bahwa untuk pembekalan wawasan kebangsaan dan kantibmas dilingkungan pondok maka Polisi dan TNI sering melakukan kunjungan ke pondok dan bertindak sebagai pembina upacara, pelatihan baris berbaris, dan membekali kepada santri tentang penting menjaga keamanan negara dari hal-hal yang mengancam keutuhan negara termasuk ancaman kelompok radikal. Menurut (Zidni, 2018) dewasa ini gencar gerakan takfiri dengan menuduh melakukan kemusyrikan yang tidak ada dalam ajaran Islam serta sunnah Rasulullah Saw. seperti hormat terhadap bendera. sasaran dari gerakan ini kaum remaja usia sekolah. Oleh karena itu, Pemikiran ini harus diluruskan dengan menghadirkan pihak kepolisian maupun tentara dari sisi kebangsaan dan dari agama oleh guru atau kiai di pondok.

Pemahaman wawasan kebangsaan perlu ditanamkan kepada setiap generasi penerus melalui berbagai media. Remaja mempunyai peran penting memajukan bangsa sehingga perlu pembinaan untuk berkiprah di bidang politik, sosial, ekonomi, dan termasuk pendidikan (Utami \& Cahyono, 2019). termasuk Sosialisasi Empat Pilar telah memberi pemahaman kepada santri terhadap empat persolan pokok bangsa Indonesia. Keempat yang dimaksud yaitu Pancasila, UUD 1945, NKRI, dan Bhineka Tunggal Ika. Semua pilar bangsa Indonesia tersebut sejalan dan sesuai dengan konsep Islam. 


\section{Pancasila}

Secara yuridis formal Pancasila menjadi ideologi dan dasar negara Republik Indonesia sebagaimana disebutkan dalam pembukaan Undang-Undang Dasar Negara Republik Indonesia Tahun 1945. Sebagai ideologi, maka perlu dilakukan penerapan dan aktualisasi dalam kehidupan bermasyarakat, berbangsa, dan bernegara dalam menghadapi persoalan kebangsaan dewasa ini.

Bahwa dalam setiap sila Pancasila memiliki hubungan yang sama dalam konsep Islam seperti sila pertama tentang tauhid, sila kedua tentang saling menghormati antar sesama manusia, sila ketiga mengandung makna pentingnya menjaga persatuan, sila keempat memiliki kehidupan bermusyawarah, serta sila kelima berisi pentingnya pemerataan dan keadilan. Semua isi yang terkandung dalam nilai Pancasila sejalan dengan tujuan Islam.

Dalam pandangan K.H. Ahmad Shiddiq (1926-1991) dalam A Helmy Zaini (Helmy Faishal Zaini, 2018) menyebutkan bahwa Pancasila membangun tiga model ukhuwah, yaitu: pertama, ukhuwah islamiyyah (persaudaraan sesama muslim) untuk mempererat persaudaraan dengan basis keislaman. Kedua, Ukhuwah wathaniyyah (persaudaraan bangsa) untuk membangun hubungan persaudaraan atas dasar kebangsaan. Ketiga, ukhuwah basyariyyah (persaudaraan umat manusia) konsep basyariyyah mengajarkan terwujudnya hubungan harmonis antar sesama manusia.

Kemudian Syafii Maarif mengatakan bahwa kehidupan demokrasi tidak bisa dilepaskan dari sikap pluralitas dan toleransi sehingga dalam konteks ini selalu menjadi bahan polemik antara Pancasila atau Islam. Organisasi besar Islam NU dan Muhammadiyah telah menerima Pancasila sebagai dasar Indonesia dan meninggalkan Piagam Djakarta dan Khilafah Islamiyah (Damanhuri, 2016). Jadi sudah cukup dengan slogan Negara Islam Indonesia yang menguras tenaga pemikiran, korban jiwa dan raga yang pernah digagas oleh R.M. Kartosuwiryo di Jawa Barat.

\section{UUD 1945}

Pelaksanaan sosialisasi empat pilar termasuk pengenalan terhadap konstitusi negara UUD 1945. Konstitusi adalah hukum dasar dalam penyelenggaraan negara yang tertulis. Dalam tata urutan perundangan yang berlaku di Indonesia UUD 1945 menempati urutan tertinggi. Pasal 29 UUD 1945 mempunyai makna tauhid pada ayat 1 berbunyi bahwa Indonesia berdasar atas ketuhanan Yang Maha Esa. Artinya, di sana ditemukan nilai-nilai tauhid yang bersesuaian dengan konsep Islam. Dengan demikian falsafah terhadap Tuhan yang maha esa dapat dipahami sebagai nilai tauhid yang menjadi inti dari ajaran Islam. kemudian dalam konstitusi juga mengandung tentang kedaulatan negara, sistem pemerintahan, dan pembagian kekuasaan.

Konsep ini ditanamkan pada santri di Pondok pesantren Hidayatullah Balikpapan. Jadi santri harus mengetahui prinsip dalam kehidupan bernegara termasuk kehidupan beragama sesuai pasal 29 UUD 1945. Kemudian santri mengetahui tentang kedaulatan negara, struktur negara, bentuk dan sistem pemerintahan, santri bisa mengetahui pembagian kekuasaan baik legislatif, eksekutif, maupun yudikatif. Pengetahuan tentang konsep ketatanegaraan terhadap santri dewasa ini menjadi sebuah keharusan sebagai bentuk pendewasaan berbangsa dan bernegara di tengah terkikisnya jiwa nasionalisme.

Helmy Faisal mengatakan (Helmy Faishal Zaini, 2018) Konstitusi negara Republik Indonesia sudah final, sehingga jika ada gagasan untuk menganti konstitusi merupakan gagasan keliru. Amandemen Undang-Undang Dasar 1945 hal yang wajar untuk menyesuaikan dengan perkembangan, tetapi mengganti konstitusi adalah kekeliruan dan fatal dalam bernegara. Selanjutnya A. Helmy Faisal Zaini mengatakan jika terjadi perdebatan tentang dasar negara yaitu mengganti dasar negara dan konstitusi bukan merupakan kemajuan melainkan langkah mundur yang jauh ke belakang dan menyedihkan. 
Dalam pandangan Hamka ia memuji klausa yang dipakai para penyusun UndangUndang dasar negara sebagai sila pertama Pancasila: sila pertama yaitu Ketuhanan Yang Maha Esa. Baginya itulah dasar negara yang otentik, meski nama Tuhan banyak, tapi hanya ada satu Tuhan. Sehingga Hamka memandang bahwa menyetujui naskah Undang-Undang Dasar 1945 tanpa mengangkat Piagam Djakarta sebab jika tidak dihapus oleh Soekarno dan para pemimpin lainnya maka Indonesia di bawah otoritas syariah. Lebih lanjut Hamka mengatakan bukan berarti Indonesia tidak bisa menjadi negara Islam, tapi tergantung pada umat. Artinya jika umat menginginkan negara Islam tergantung siapa pemimpin dan para umat Islam. Dalam hal ini Hamka menginginkan negara Islam yang dimaksud adalah "masyarakat Islam"(Rahmanto, 2018). Oleh karena itu, tidak ada klausul yang membenarkan bahwa pancasila tidak sejalan dengan paradigma Islam seperti pada sila pertama Pancasila dan pada Alinea ketiga pembukaan UUD 1945.

\section{NKRI}

Komitmen Pondok Pesantren Hidayatullah Balikpapan terhadap NKRI tercermin banyaknya kader yang tersebar seluruh nusantara ada ratusan jumlah cabang Hidayatullah dengan tujuan gerakan Tarbiyah dan Dakwah. Hal ini menujukkan kepedulian Pondok Pesantren Hidayatullah untuk menjaga NKRI tidak dapat dikesampingkan. Dengan modal tauhid mereka mampu bertahan menebar ilmu pengetahuan dan dakwah Islam untuk tercapainya cita-cita Islam. Agar tujuan dapat tercapai, maka santri yang diberi tugas harus mampu melakukan kerjasama dengan masyarakat, tokoh agama, dan pemerintah. Jadi apa yang dijalankan santri disetiap daerah sesuai dengan arah Undang-Undang Dasar 1945 pada pasal 1 ayat 1 mengandung prinsip bahwa negara Indonesia adalah negara kesatuan yang berbentuk republik. Kemudian dipertegas lagi pada pasal 18 ayat 1 UUD 1945 bahwa Negara Kesatuan republik Indonesia dibagi atas daerah-daerah perovinsi dan daerah provinsi dibagi atas kabupaten dan kota dan tiap-tiap kabupaten kota itu mempunyai pemerintahan dan diatur dengan undang-undang.
Sejak awal masuknya Islam ke Indonesia sampai pasca reformasi, pesantren telah berkonstribusi besar terhadap Negara Kesatuan Republik Indonesia (NKRI). Hal dapat dilihat kiprah para kiai dan para santrinya dari aspek kehidupan termasuk perjuangan dalam merebut kemerdekaan maupun dalam pembangunan mengisi kemerdekaan terutama dalam pendidikan dan dakwah Islam. Oleh karena itu, maka sepatutnya pemerintah memperhatikan pondok pesantren dan umat Islam dalam membangun NKRI khususnya bidang pendidikan (Pesantren et al., 2016).

Mempertahankan Negara Kesatuan Republik Indonesia menjadi tanggung jawab semua elemen bangsa. Sejarah mencat at profil pesantren di Indonesia mempunyai vitalitas terhadap pendidikan. Jumlah lembaga pendidikan pesantren memberikan pengaruh besar bahwa peran pesantren dalam membangun dan mempertahankan Negara Kesatuan Negara Republik Indonesia. Demikian halnya kehadiran Pondok Pesantren Hidayatullah Balikpapan hadir untuk menghimpun semua golongan. Oleh karena itu, pesantren berupaya memperkuat perannya memajukan bangsa Indonesia dalam berbagai aspek kehidupan agar tercapai tujuan pembangunan nasional dan tetap utuh Negara Kesatuan Republik Indonesia (NKRI).

\section{Bhinneka Tunggal Ika}

Konsep kebhinnekaan dalam Islam dikenal dalam QS. Al-Hujurat/49: 10 dan QS. Al-Hujurat/49: 13. Ayat secara lugas menyampaikan bahwa Allah menciptakan manusia berbangsa-bangsa dan bersuku-suku agar saling kenal mengenal dalam kitab ibnu katsir kata syu'ub orang non Arab sedangkan kata Qabail adalah orang Arab. Kemudian Imam At-Thabari menafsirkan yang pada prinsipnya sama yaitu kata Syu'ub diartikan sebagai keturunan jauh (nasaban ba'idan) sedangkan kata Qabail (nasaban qariban) keturunan dekat (Islam, 2018)

Sejalan dengan itu di Pondok Pesantren Hidayatullah Balikpapan tidak mengenal perbedaan stat us sosial, ekonomi, suku, dan ras. Dengan begitu, nampak bahwa di pondok tidak diajarkan perbedaan latar belakang demikian halnya dengan golongan, paham, dan berbagai kelompok keagamaan 
dalam masyarakat. Jadi santri hanya mengetahui bahwa golongan tersebut ada, tetapi tidak ada kewajiban untuk terlibat dalam golongan tersebut. Pentingnya sosialisasi dan pemahaman terhadap empat pilar terhadap santri menjadi bekal ketika santri ditugaskan ke daerah untuk program pendidikan ataupun dakwah, maka penting untuk mengetahui bagaimana kondisi sisial masyarakat yang akan ditugaskan. Inilah mendasari sehingga proses ini harus ada dan menjadi pedoman bagi santri sebagai warga negara.

\section{PENUTUP}

Pembelajaran keislaman di Pondok Pesantren Hidayatullah secara garis besar terdiri dari tiga yaitu Tauhid, Akidah, dan Akhlak. Asas kuirkulum yaitu tauhidullah dimaksudkan untuk memperkokoh nilai tauhid sehingga materi pelajaran harus mengandung nilai-nilai tauhid. Kemudian dalam ibadah bagaimana menbentuk santri menjadi insan kamil dengan melaksanakan shalat Tahajjud, Baca al-Qur'an, Dzikir, Tawakkal, Puasa Senin Kamis, Ta'lim, Halaqah al-Qur'an. Kemudian pembentukan akhlakul karimah dengan saling menghormati, hidup sederhana, serta berinteraksi dengan masyarakat.

Pembelajaran keindonesiaan diberikan kepada santri Pondok Pesantren Hidayatullah Balikpapan sebagai bentuk kecintaan terhadap tanah air Indonesia. Pembelajaran yang dilakukan yaitu Bahasa Indonesia, PKn, IPS, Matematika, Olah Raga, dan Seni Budaya. Kegiatan pembelajaran keindonesiaan diluar kelas yaitu adanya sosialisasi empat pilar (Pancasila, UUD 1945, NKRI, dan Bhineka Tunggal Ika). Kemudian pondok juga membentuk Satuan Komunitas (SAKO) Pramuka Hidayatullah Balikpapan, dan kegiatan eskul wajib yang lain seperti bela diri, kemudian secara berkala ada pembinaan dari pihak kepolisian dan TNI.

\section{UCAPAN TERIMA KASIH}

Ucapan terima kasih dan apresiasi yang setinggi-tingginya saya khaturkan kepada pengurus yayasan Pondok Pesantren Hidayatullah Balikpapan Lembaga Pendidikan Pengkaderan Hidayatullah (LPPH) Balikpapan yang memfasilitasi peneliti dalam pengambilan data. Kepada seluruh informan terima kasih telah memberikan data yang tentu sangat berharga dalam penelitian ini. Kepada seluruh pihak yang telah membantu peneliti sehingga bisa terwujud dalam bentuk jurnal.

\section{DAFTAR PUSTAKA}

Damanhuri, D. (2016). Islam, Keindonesiaan, Dan Kemanusiaan (Telaah Pemikiran Ahmad Syafii Maarif). Al-Banjari: Jurnal Ilmiah Ilmu-Ilmu Keislaman, 14(1). https://doi.org/10.18592/albanjari.v14i1.644

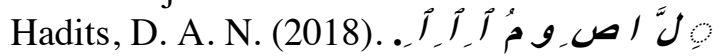
4.

Helmy Faishal Zaini, A. (2018). Nasionalisme Kaum Sarungan (R. B. E. A. Nugroho (ed.)). kompas Media Nusantara. buku@kompas.com

Islam, J. P. (2018). Jurnal Pemikiran Islam Vol. 4 No. 2 Desember 2018.4(2), 1-18.

Oemar Hamalik. (2013). Kurikulum dan Pembelajaran (13 ed.). Bumi Aksara.

Pesantren, P., Kalijaga, S., \& Muria, S. (2016). Kontribusi pondok pesantren terhadap nkri. 3(1), 21-43.

Rahmanto, M. (2018). Hamka dan Tafsir Harmonisasi Keislaman dan Keindonesiaan. Afkaruna, 14(1), 133145.

https://doi.org/10.18196/aiijis.2018.008 4.133-145

Salbu, M. (2012). Mencetak Kader: Perjalanan Hidup Ustadz Abdullah Said Pendiri Hidayatullah (P. Utomo (ed.); II). Lentera Optima Pustaka. publishing@hidayatullah.com

Tafsir, A. (2013). Ilmu Pendidikan Islam (E. Kuswandi (ed.); II). Remaja Rosdakarya. rosdakarya@rosda.co..id

Tang S, M. (2017). Transformasi Konsep Pendidikan Tauhid K.H. Abdullah Said. (Muslimah (ed.); pertama). Aswaja Pressindo. aswajapressindo@gmail. com 
Toharudin, T. (2018). Nilai-Nilai Keislaman dan Keindonesiaan dalam Membentuk Karakteristik Peradaban Melayu di Indonesia (Studi Pemikiran Munawir Sjadzali). Jurnal Intelektualita: Keislaman, Sosial dan Sains, 7(1), 4158. https://doi.org/10.19109/intelektualita.v7i1.2340

Utami, P. S., \& Cahyono, H. (2019). JPE ( Jurnal Pendidikan Edutama) Vol . 6 No . 1 Januari 2019. 6(1), 87-98.
Wahidin, unang; Ahmad, S. (2018). Jurnal Edukasi Islami Jurnal Pendidikan Islam Vol . 07 / No . 1 , Teori-Teori Pendidikan ... Teori-Teori Pendidikan .... Jurnal Pendidikan Islam, 07(1), 4766. https://doi.org/10.30868/EI.V7

Zidni, E. S. Z. (2018). Kemitraan Keluarga dalam Menangkal Radikalisme. Jurnal Online Studi Al-Qur'an, 14(1), 32-43. https://doi.org/10.21009/jsq.014.1.03 
